\title{
Economic and Ecological Transformation Processes in East German Water Management Regimes: The Role of Property Rights and Governance Structures
}

\author{
Christian Schleyer
}

CEESA Discussion Paper No. 9 | 2002

ISSN 1616-9166

\begin{abstract}
Like in many low moor regions in East Germany, long-standing intensive arable farming enabled by complex melioration - has caused soil deterioration and high water runoff in the 'Schraden'. More than ten years of economic and political transformation has worsened the situation and even added new problems. The visible consequences are drought periods in the summer, waterlogged plots in the spring and worn-down water management facilities that operate in an uncoordinated or even unauthorised way.

It is here argued that the reallocation of property rights on melioration systems, together with ineffective co-ordination mechanisms, have impeded appropriate land use. Transformation-related problems like the discontinuity of land property rights, the unclear legal situation regarding melioration plants built in socialist times, and highly-fragmented land ownership have not been effectively dealt with by the newly-established Water Association and Water Administration, respectively. Profoundly heterogeneous water-user interests and the complexity of ecosystem relations have contributed to the persistence of the problems.

This analysis is based on regional planning material as well as on qualitative, semistructured interviews with local stakeholders, representatives of the administration and politicians at all levels of government.
\end{abstract}


About the author:

Christian Schleyer is currently working on his doctoral thesis on 'Institutional Change of Water Management Systems' at the Chair of Resource Economics of Humboldt University Berlin. He graduated as an economist from the department of Economics and Business Administration. His main research interests are institutional economics and water management issues.

Contact: christian_schley@hotmail.com

\section{Acknowledgements}

The context of this paper is the recently completed GRANO project, a co-operative project of research institutions from Berlin and Brandenburg. This project's objective was to develop and implement approaches for sustainable agricultural production in Northeast Germany, taking into account economic, socio-cultural, ecological and environmental concerns. The activities were focused on two research regions - one of them being the low moor region 'Schraden'. For the final report, see MÜLLER et. al., 2002.

The author gratefully acknowledges fruitful discussions within the GRANO Research Group, in particular with Katja Arzt, Carsten Berg, Ursula Peters and Silke Schwolow, as well as ideas and comments from Andrew Cattermole, Konrad Hagedorn, Lutz Laschewski, Philip Lowe, Ivan Penov, Jeremy Phillipson, Christiane Ratschow, Thomas Sikor, Insa Theesfeld and Adam Wasiliewski 


\section{Contents}

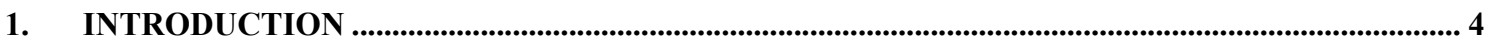

2. DEVELOPMENT OF MELIORATION SYSTEMS PRIOR TO 1990................................................ 6

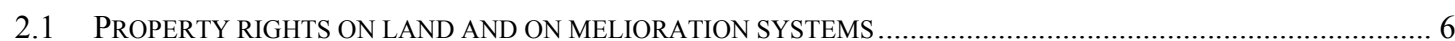

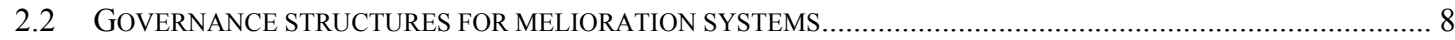

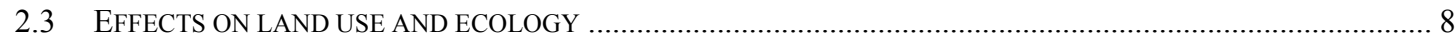

3. MELIORATION SYSTEMS IN TRANSFORMATION SINCE 1990 ..............................................9

3.1 CHANGES IN PROPERTY RIGHTS ON LAND AND MELIORATION SYSTEMS ............................................... 10

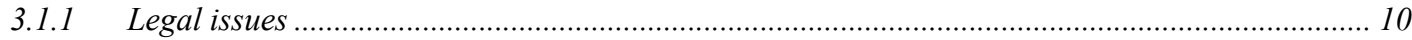

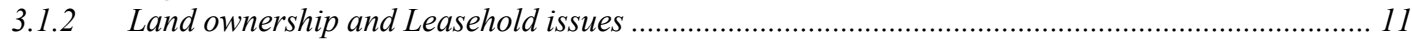

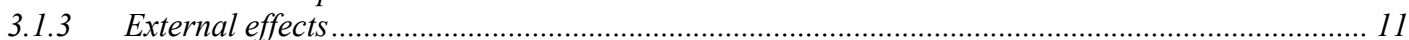

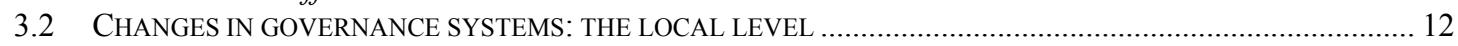

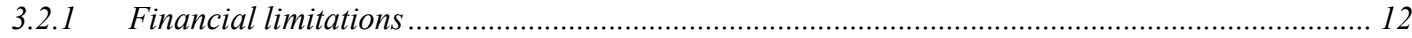

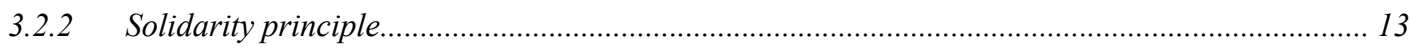

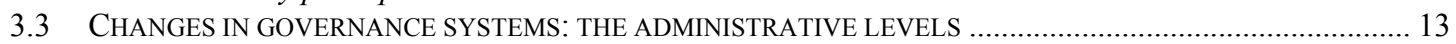

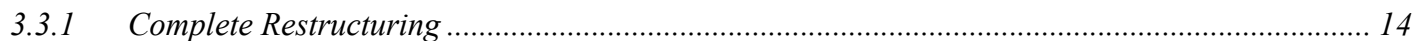

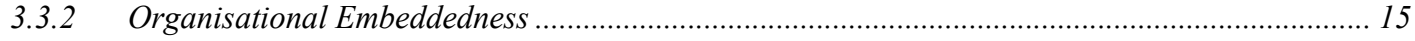

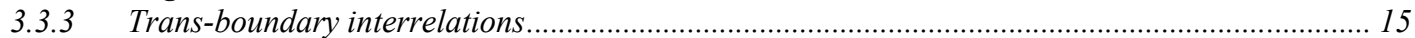

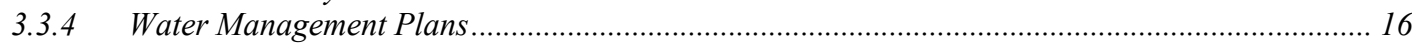

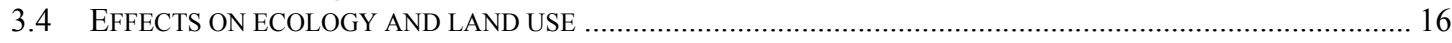

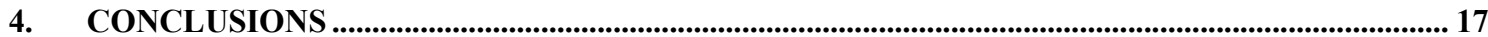

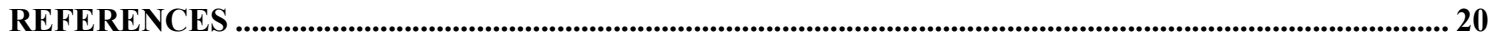




\section{Introduction}

Like in many low moor regions in East Germany, long-standing intensive arable farming enabled by complex melioration ${ }^{1}$ - has caused soil deterioration and high water runoff in the 'Schraden'. More than ten years of economic and political transformation has worsened the situation and even added new problems. The visible consequences are drought periods in the summer, waterlogged plots in the spring and worn-down water management facilities that operate in an uncoordinated or even unauthorised way.

These water-related agri-environmental problems are, to varying degrees, typical for many low moor regions in Brandenburg and East Germany. There, political priorities have only recently started to focus on the landscape water regime. However, predominantly technical solutions such as increased financial support for Water Associations, and for practical measures which help keep water in the regions longer, have been brought forward (Landgraf, 2001). That said, a variety of recent research points out that more than merely additional or optimised instruments are needed to deal with complex and dynamic agri-environmental problems. Within this research the role of property rights and governance structures for a sustainable management of common pool resources like water is frequently stressed (Ostrom, 1998; Vermillion, 1999; Meinzen-Dick and Knox, 1999).

Furthermore, the need for institutional change towards institutions of (environmental) sustainability is postulated. It is argued that specific ecosystem characteristics require adequate property rights regimes and appropriate governance structures (Hagedorn, Arzt and Peters, 2002). The presented case also relates to a country in transition: East Germany is experiencing drastic changes in the economic and political system as well as land restitution, property rights formation processes and agricultural restructuring. It therefore seems reasonable to ask if such a "two-fold transformation" can possibly be achieved simultaneously (Hagedorn and Gatzweiler, 2002; Hagedorn, 2002). In order to develop institutions of (environmental) sustainability with regard to water management, it is of vital importance to understand and interpret the transition-related changes in property rights regimes and governance structures in this field.

In this paper, it is argued that the reallocation of property rights for melioration systems, together with ineffective co-ordination mechanisms, have impeded appropriate land use in the

\footnotetext{
${ }^{1}$ Generally, (complex) melioration measures are all measures which lead to a sustainable increase of productivity and cultivability of agriculturally or forestal used areas (KÖNKER, 1991: 147). This also includes (rural) road construction and structuring land. However, only hydromelioration measures like drainage and irrigation are being discussed in this paper.
} 
'Schraden'. In view of this, the paper explores the impact of transition-related changes upon property rights (on melioration systems as well as on land), governance structures and water user interests. Furthermore, it investigates how these changes are related to this problem, what impact they have on land use and ecology, and what lessons can be learned from the analysis.

Section 2 will give a brief overview of the technical development, property rights regimes and governance structures before transition began in 1990. Furthermore, the underlying interest structure and the effects on land use and ecology are presented and discussed. Section 3 will briefly describe the changes in interest structure, property rights regimes and governance structures during the transformation, and will discuss related problems and deficiencies in detail. The accompanying effects on land use and ecology are also highlighted. The final section summarises the findings and draws some conclusions.

The paper is based on the analysis of qualitative, semi-structured interviews with local stakeholders such as farmers, environmentalists and associations, but also with representatives of the administration and politicians on all levels of government. Moreover, available planning materials, regional statistics and other available local information for the region were consulted. Nevertheless, this paper primarily summarises and clusters the relevant stakeholders' subjective perceptions of the problems which they face. 


\section{Development of melioration systems prior to 1990}

In the low moor region 'Schraden', the first melioration measures were carried out in the $15^{\text {th }}$ century. They were intensified in the second half of the $19^{\text {th }}$ century mainly for the extension of grassland farming in an area that was still dominated by inaccessible alder forests and swamps. Furthermore, it was intended to reduce the often disastrous effects of seasonal floods on the villages and towns in the region, and to minimise health risks like malaria that are associated with extensive swamps (AVP, 1998: 12). In the 1960s and 70s, melioration measures found their peak in the 'complex melioration' carried out in the German Democratic Republic (GDR). Here, one of the central objectives was the intensification of agricultural production in order to reach (national) subsistence farming targets and subsequently even to export agricultural products. Therefore, the logical consequence was "to eliminate obstacles which slow down (agri-) industrial production", (Dokumentation ...1977 as cited in AVP, 1998: 8f., own translation), such as the annual flooding or waterlogging of land, and to turn ground water-dominated land - often used as grassland - into more productive arable land. Large drainage systems, mostly open ditches but also various forms of underdrainage, were built to 'optimise' the ground water table. This system of ditches and channels was also equipped with weirs, dam plants and pumping stations to enable irrigation by flood and even by infiltration if necessary. By 1997, there were 330 different ditches and small channels of about 300 kilometres in total length, equipped with about 170 weirs and dam plants, that were able to regulate the water table in the whole 'Schraden', which covers about 10,000 ha of agricultural land (AVP, 1998: 33ff). The melioration infrastructure was designed to cover the entire area and to meet the needs of large agricultural firms farming very large plots. The relatively low number of weirs compared with the total length of the ditches indicates that there was no need to regulate the water table for small plots.

\subsection{Property rights on land and on melioration systems}

Apart from big land owners, who had their land appropriated before 1949 under Soviet occupation, and some exceptional cases, the vast majority of private farmers and land owners in the GDR were not formally expropriated (Peinemann, 1995: 225ff; Laschewski, 1998). However, during collectivisation, they were forced to bring their assets into collectivelyorganised production units (Swinnen and Mathijs, 1997). Hence, only usage rights were allocated to these agricultural firms, which were integrated in the central-planning system. Essentially, this meant that land owners had little or no influence regarding their own interests 
(Schüler, 1991: 34f). Further, because a land rent was not paid, formal property rights became meaningless. Because of that, the distribution of land was kept fragmented almost as it was in the 1950s, while the agricultural firm structure underwent immense changes (Laschewski, 1998). As can practically be seen in the 'Schraden', these changes, in qualitative terms, were often linked to comprehensive land consolidation measures and extensive melioration measures. In other words, plots that had little infrastructure before might now be found 'enriched' with ditches, weirs and dam plants (see also Swinnen and Mathijs, 1997, for similar observations in CEE Countries). These assets of the newly built melioration systems were regarded as collective property. Nevertheless, firm responsibilities and rights for specific categories of the melioration system - rather than formal property rights - had been allocated to different organisations and administrative levels ${ }^{2}$, as is outlined in Figure 1:

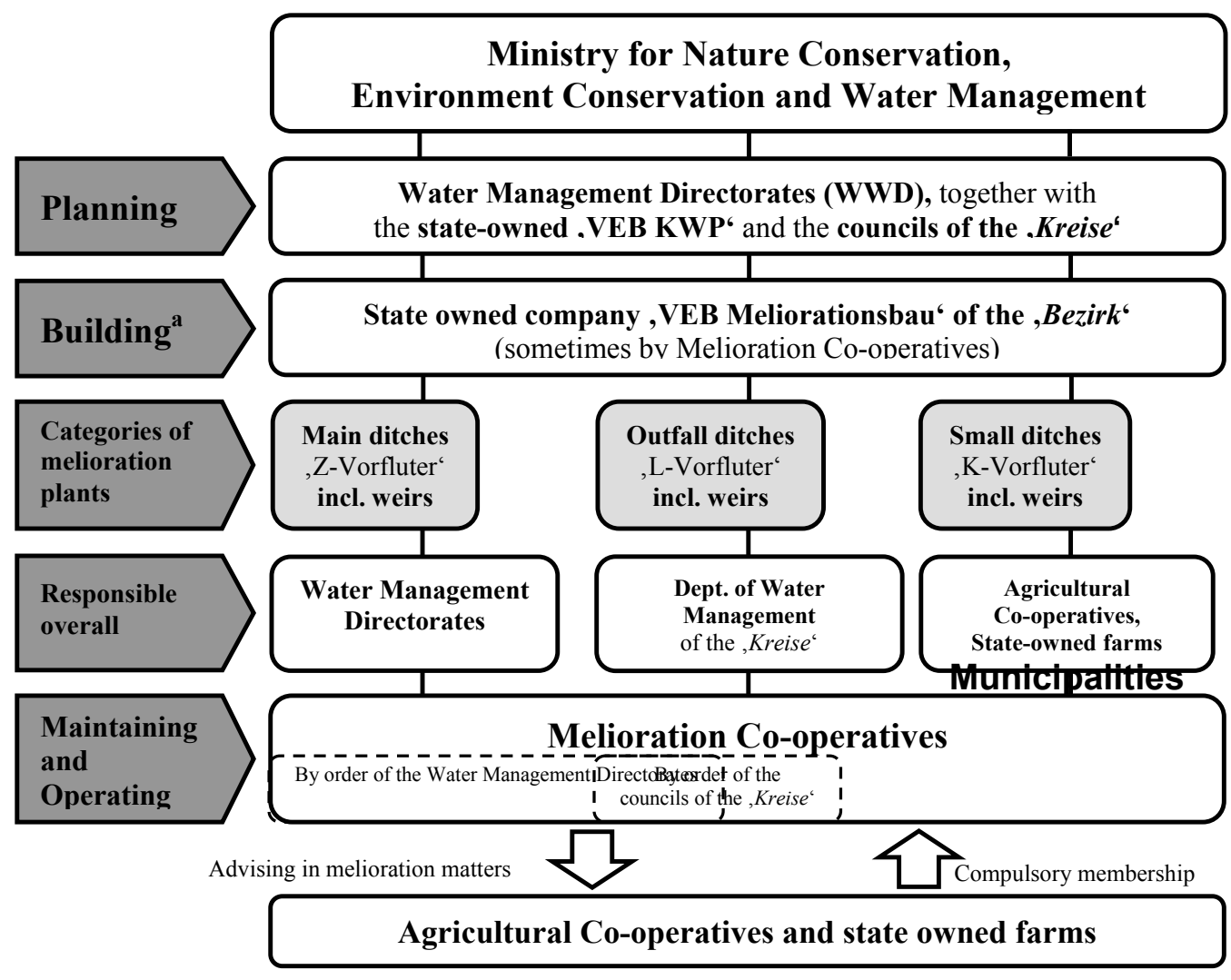

${ }^{\text {a }}$ Financed in varying degrees by funds from agricultural firms, low-interest-loans and state subsidies.

Figure 1: Allocation of responsibilities with regard to melioration systems in the GDR

\footnotetext{
${ }^{2}$ In the GDR, there were 15 counties ('Bezirke'). Each 'Bezirk' consisted of several rural or urban districts ('Kreise'), which administrated the cities and municipalities, ('Gemeinden').
} 


\subsection{Governance structures for melioration systems}

Figure 1 shows that planning, building and, partially, financing responsibilities were predominantly aggregated at upper local levels. In contrast, most of the maintenance and operation activities were delegated to local melioration co-operatives with compulsory membership for all agricultural firms. Supported by the Water Management Directorates (WWD) and the Departments of Water Management at the 'Kreis' level, these large-unit firms could easily provide the necessary technical infrastructure, human resources and financial means to maintain and operate, as members of the melioration co-operative, the lion's share of the infrastructure. Since increasing agricultural production was the overriding goal for all firms and because a well-functioning melioration system safeguarded high production yields, the interest structure among the firms regarding maintenance and operation was fairly homogeneous. Co-ordination of those activities was also facilitated by the large size of the production units. As was pointed out during many interviews, local actors perceived this structure as well-functioning and smoothly and satisfyingly-operating.

\subsection{Effects on land use and ecology}

The extension of drainage activities almost immediately resulted in a drastically lower water table, which enabled a change in land use towards increasingly-intensive arable farming. The whole 'Schraden' area covers circa 11,400 ha. Presently, about $88 \%$ of this land is used as agricultural land, predominantly for arable farming. Forests cover only about $2 \%$. However, long-standing intensive arable farming of this meliorated low moor has led to an increasing, mostly irreversible degradation of soil (e.g., bog subsidence). During arid periods, the soils run dry and lose more and more fertile soil and organic matter due to wind erosion. ${ }^{3}$ Soil degradation, together with soil compaction from the use of heavy machinery, has led to the increasing inability of the soil to hold water; thus, a high level of water runoff will be experienced if not held back by well-functioning and co-ordinated weirs and dam plants. This becomes even more important since the overall water balance in Brandenburg is negative ${ }^{4}$. Furthermore, the extensive use of fertilisers and pesticides in the 'Schraden', fostered by the relatively high water table and the high permeability of the soil substratum, has caused

\footnotetext{
${ }^{3}$ Interestingly, the negative effects of drainage on the low moors in Brandenburg, in general, were already officially perceived in 1987, when LEHRKAMP (1987) noted that due to soil degradation the average yield of arable farming had fallen back to the pre-complex melioration level in some areas in the Randow-WelseBruch in Brandenburg.

${ }^{4}$ Despite Brandenburg being the 'Land' with most lakes and open waters in Germany, it suffers from a lack of water, especially in the summer. The reasons are over-drainage, predominantly sandy soils, decreasing ground water levels caused by open cast mining, and a negative climatic water balance in some regions (LANDGRAF, 2001; KALWEIT, 1998).
} 
groundwater pollution. Another negative environmental effect can be seen in the extremely low ecological value and very low self-cleaning ability of the highly regulated, mostly artificial running waters (AVP, 1998).

Such severe environmental problems caused by hydromelioration measures - drainage and irrigation - have also been observed in many other countries. They "are not solely restricted to increasing pollution or loss of habitat for native plants and animals; they cover the entire range of environmental components, such as soil, water, air, energy, and the socio-economic system." Some of those measures even "...threaten the long-term productivity of the irrigation and drainage projects themselves, as well as the natural resource base." (Dougherty and Hall, 1995: iii). In particular, drainage can be seen as a "source of cumulative [environmental] effects because of its temporally repetitive and spatially expansive nature." (Spaling and Smit, 1995: 99). Some of the environmental effects, however, are more indirect. In many cases, melioration measures only enable intensive, arable land use - e.g., on former low moors, wetlands, etc. - accompanied by soil erosion, soil compaction, pollution with nitrates and pesticides, often monotonous field structures and loss of biodiversity (AVP, 1998; Turnock, 1998). These effects are especially severe in transition countries, where successes in agriculture are often based on the "plundering of the natural resources" (Turnock, 1998: 385).

\section{Melioration systems in transformation since 1990}

Until 1989, all interests regarding the management of the melioration system had been secondary to agricultural production goals. However, the interest structure significantly diversified after unification. The respective requirements, primarily concerning the ground water table, of the newly restructured and re-organised agricultural firms have become very heterogeneous, and now very much depend on farm size and location (e.g., upstream or downstream), crop structure and economic performance. Presently, thirteen different agricultural enterprises farm the agricultural land in the 'Schraden' (AVP, 1998: 78).

Furthermore, as the interviews showed, interests regarding nature conservation have become much more prominent. Though conservationists generally agree on higher ground water tables, and often join forces to bring the degradation of the low moor to a halt, different visions of the future 'Schraden' prevail. These include the vision of a sustainable, appropriate or more habitat-adapted form of agricultural land use, but also aim to reverse the degradation process as far as possible, including the prevention of agricultural land use.

As became clear during the interviews, farming and nature conservation are not the only divergent interests. Other interest groups like industry, housing/settlement construction and 
transport services demand 'safe' ground water tables to avoid flooding and other damages. For example, operators of gravel pits in this region require sufficient flood protection to make open cast mining possible. On the other hand, they need a sufficiently high ground water table in order to use floating excavators.

\subsection{Changes in property rights on land and melioration systems}

Shortly after unification, collectivised land in the 'Schraden' was restituted to the legal owners, with full property rights being returned to them. By doing this, the fragmented land ownership structure was basically revived. However, most of the new/old land owners quickly leased their land to the newly restructured and re-organised co-operatives; these are now joint stock companies, limited liability companies or producer co-operatives. Compared with the former co-operatives, the new agricultural firms are smaller, more focused enterprises predominantly farming on leased land.

In 1994, the Brandenburg Water Act finally replaced the GDR Water Act, formally reorganising, among other things, the responsibilities and rights for rivers, channels and ditches and separating them into two categories (BbgWG). Only those belonging to the (new) $1^{\text {st }}$ order were declared property of the 'Land' ${ }^{, 5}$ and consequently had to be taken care of by the 'Land'. Regarding the melioration systems, only some of the former 'Z-Vorfluter' now belong to this $1^{\text {st }}$ category. As determined in $\S 5$ of the Brandenburg Water Act, corresponding with $\S \S 10$ and 12 of the federal Law on Melioration Plants (MeAnlG), all open waters of the $2^{\text {nd }}$ order, including the weirs and dam plants, were to become legal property of the owners of the bordering lands. In the following sections, some rather problematic implications of these changes in interest and property rights will be highlighted.

\subsubsection{Legal issues}

After unification and until the introduction of the Brandenburg Water Act in 1994, the future legal status - and hence the rights and responsibilities for maintenance and operation - of the melioration systems had been unclear. But the new law did not fully solve the problem because, firstly, the related federal Law on Melioration Plants of 1994 only explicitly ruled on the property rights of 'drainage' works on $2^{\text {nd }}$ order waters ( $\S 12 \mathrm{MeAnlG}$ ). They now belonged to the respective land owners that bordered the open waters. However, most weirs and dam plants were intended, and built, for 'irrigation' use not covered by this clause

\footnotetext{
${ }^{5}$ In the Federal Republic of Germany, there are 16 states ('Länder'). Each 'Land' consists of several rural or urban districts ('Landkreise'), which administrate cities and municipalities, ('Gemeinden').
} 
(Pollack, 1991: 18). The same law determined that these 'irrigation' works should only become property of the land owners from the year 2000 onwards ( $§ 10 \mathrm{MeAnlG})$. Secondly, as the interview with a representative of the Lower Water Agency revealed, Water Authorities could not enforce the related duties or responsibilities because land owners could not be held legally responsible for assets on their land - such as ditches or weirs - they had neither wanted nor built directly. ${ }^{6}$ Here, the issue of 'successors in interest' to the organisations and administrative authorities once responsible for the melioration infrastructure before 1990 was, and still is, widely pending.

\subsubsection{Land ownership and Leasehold issues}

After the restitution of land in the 'Schraden', almost all of the owners decided to lease their land to new agricultural enterprises instead of starting their own farming business or using the land for other purposes. Following the statements of interviewed tenants, most of the land owners do not know about the melioration works on their land or are not aware of the related (legal) rights and duties. What is more, many owners no longer live in the region, have nothing to do with the farming business and own only very small plots. There are also cases where the owners are not known, cannot be found or the ownership is legally disputed. However, in every case, the owner of, for example, a weir would have to agree explicitly to any maintenance or operating measures to be carried out. Otherwise, the very activity would be regarded as illegal. It is only a recent development that most new or renewed lease contracts contain some clause transferring all rights and duties related to the melioration works to the tenant for the time of the lease.

\subsubsection{External effects}

The problems mentioned above are exacerbated by the farmers' argument that individual costs for the maintenance and operation of the weirs and dam plants would result in nonexclusive benefits since a functioning and operated weir, e.g., enabling a sufficiently high ground water table to avoid draught, does not simply benefit the individual farmers' plot. In most cases, it would be technically impossible to avoid positive external effects for neighbouring farmers. More importantly, there would be no means to make other beneficiaries share these considerably high costs. In turn, operating - perhaps illegally - a weir causing waterlogging on plots of a neighbouring farmer might result in either high social

\footnotetext{
${ }^{6}$ It is interesting to note that on the one hand, owners refuse to take on duties related to 'unwillingly-inherited' melioration works. But virtually nobody complains about the changed quality and higher value of the now arable land enabled solely by these works (for a similar observation, see HAGEDORN, 2002: 8f).
} 
costs, or an unwanted charge at the Water Authority. This holds even more true since all measures which put the ground water table above or below a certain level have to be approved by the Lower Water Authority ( $\S 37$ and $51 \mathrm{BbgWG}$ ).

To sum up, external effects and legal insecurities, together with a fragmented land ownership structure and a high number of short-term lease contracts have reduced the incentives for most farmers to maintain, invest in, or (officially) operate the assets in question. As a consequence, melioration works with purely local importance were basically left to their own since 1989, and have since been operated haphazardly, individually and mostly illegally (AVP, 1998).

\subsection{Changes in governance systems: the local level}

At the local level, the large co-operatives disintegrated into smaller and more focused enterprises with different legal forms and ownership structures (see also Wiegand, 1994 and Laschewski, 1998). As a consequence, the melioration co-operatives - inter-firm organisations of enterprises which directly competed in the market - were soon dissolved without substitute. However, in order to ensure the necessary runoff of water and hence to avoid damage by floods or a high ground water table, the 26 Water Associations, 'Wasser- und Bodenverbände' were formally enacted by the Brandenburg Water Act of 1994, in conjunction with the Brandenburg Water Association Act of 1995, to take over the maintenance and cleaning duties of $2^{\text {nd }}$ order ditches, or more generally, to "ensure the functionality of the open waters" ( $\S 78$ and 79 BbgWG, own translation; BbgWVG, WVG). These Water Associations were founded in the years after the unification but prior to the passing of these acts. For the 'Schraden' area, the Water Association 'Kleine-Elster Pulsnitz' has taken over these responsibilities and is supervised by the 'Land' Environment Agency (§ 80(4) BbgWG). It is compulsory for all municipalities, representing those land owners subject to land rates ('Grundsteuern') to be members of the Associations (§ 2(1) BbgWVG). ${ }^{7}$ As the interviews with farmers confirmed, the tenants effectively pay the membership fee as an implicit part of the rent. The following sections will discuss some of the problems related to these local-level changes.

\subsubsection{Financial limitations}

Like other Water Associations in Brandenburg, the activities of the regional Water Association 'Kleine Elster-Pulsnitz' have to be financed solely by membership fees since

\footnotetext{
${ }^{7}$ Additionally, other beneficiaries, e.g., railway companies, can be voluntary members (§ 2(2) BbgWVG).
} 
practically no regular subsidies from the 'Land' are being paid. As stated by representatives of the Water Association, the available funds are only sufficient to do the compulsory tasks basically maintaining and cleaning the ditches. The owner of the respective land has to tolerate these activities ( $§ 84 \mathrm{BbgWG}$ ). However, non-compulsory measures like maintaining or operating the weirs or dam plants are only carried out occasionally and if spare funds are available. What is more, before beginning with any of those activities the respective owner or tenant - has to agree explicitly.

Instruments to mitigate the problem include state support programs, which could be used at least for project-related maintenance tasks, but not for covering operating costs. However, depending on the program, the Water Association or another corporate body has to co-finance these funds with between $20 \%$ and $50 \%$ of their own funds. Here again, the capital resources of the Water Association are stated as the limiting factor.

\subsubsection{Solidarity principle}

Theoretically, the financial limitations of the Water Association could be eased by higher membership fees in order to make it financially 'profitable' to take care of the weirs and dam plants. However, many of the interviews indicated that these fees are already perceived as rather high by contributors in the region and a further increase seems politically unacceptable. Furthermore, there is no differentiation in membership fees corresponding to the real distribution of benefits of the association's activities. Whereas the federal Water Associations Act (WVG) allows for this differentiation, a solidarity principle was adopted for the Brandenburg Water Act. In other words, the membership fees can only be proportionate to land size (§ 80(1) BbgWG).

Overall, the present Water Association appears to be an inadequate substitute for the dissolved melioration co-operatives due to its limited statutory rights and its small financial room for manoeuvre.

\subsection{Changes in governance systems: the administrative levels}

Concerning the water management and planning system at the administrative levels, no substantial implementations of new rules and structures took place until 1992, when the Water Management Directorate 'Oder Havel', which had been responsible for the Brandenburg territory, was dissolved (Verordnung, 1992). In Brandenburg, only those tasks for which the Water Management Directorates and the 'Kreise' had been responsible were safeguarded by the 'Land' Environment Agency '('Landesumweltamt'), which operated like a 'successor in interest' to the ' $W W D$ '. In 1994, the Brandenburg Water Act established a new administrative 
structure which basically follows the example of the old 'Länder', putting emphasis on selfgovernment on the communal level. Figure 2 gives a brief overview of the different administrative layers of Water Authorities and Water Agencies in Brandenburg in relation to the 'Landkreis Elbe-Elster'.

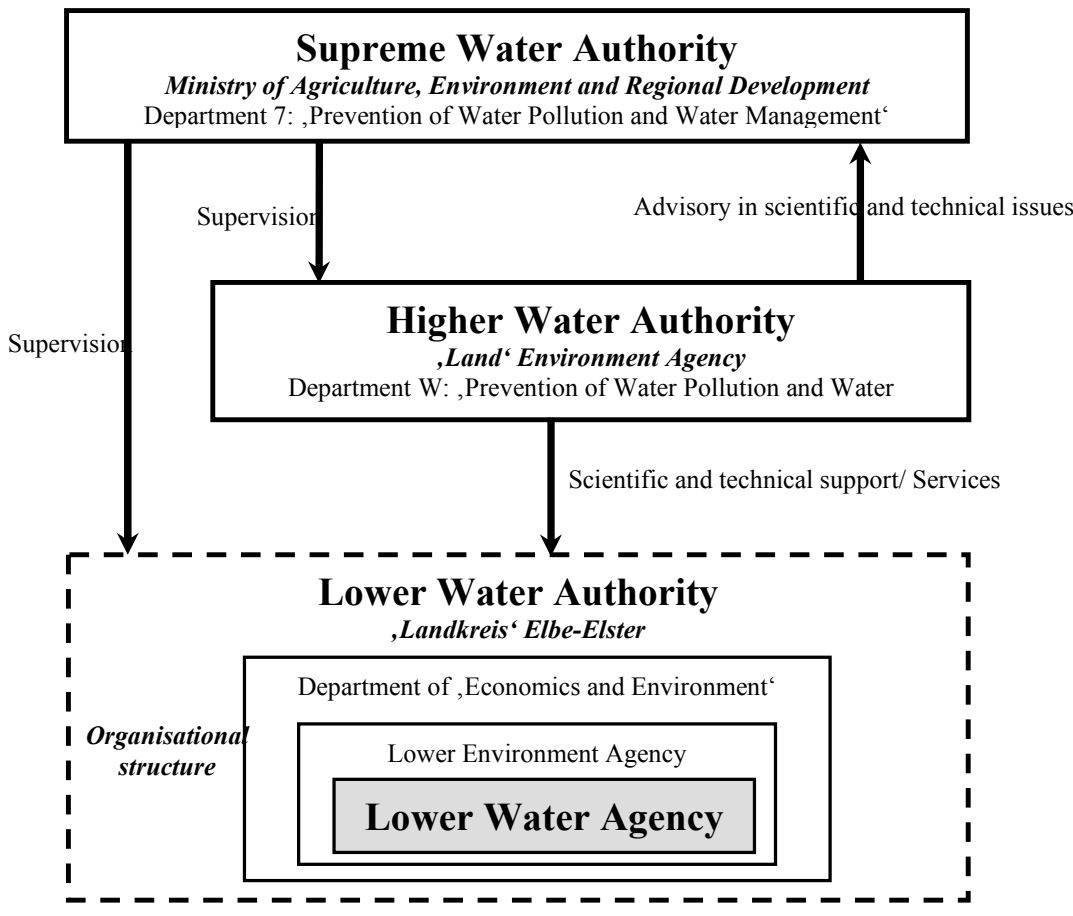

Figure 2: Administrative layers of Brandenburg's Water Authorities and Water Agencies in relation to the 'Landkreis Elbe-Elster'

In the following sections, some of the administration-related problems will be discussed in greater detail.

\subsubsection{Complete Restructuring}

As taken from the interviews with representatives from the Lower Water Agency in the 'Landkreis Elbe-Elster', the restructuring process has been experienced as drastic and complete, but not smooth. It was stated that almost all relations between the different levels of the newly-established Water Authorities had to be rebuilt from scratch. This process has not yet been completed satisfactorily and still confines inter-authority communication to that which is absolutely necessary. The process of old and new civil servants gathering competence in the newly established laws and rules and exploring new rooms for manoeuvre was described as time consuming and toilsome. The same would hold true for the relations of the Water Authorities to water users, (water) associations and interest groups, other administrative agencies, the municipalities and the general public. This would have been 
exacerbated by the fact that the restructuring followed completely new administrative and political structures.

\subsubsection{Organisational Embeddedness}

As shown in Figure 2, the Lower Water Authority is operating at the 'Landkreis' level, meaning that practically all decisions related to water management are made from the viewpoint of the 'Landkreis' as a whole. In other words, the eventual power of decision making in this field rests with the 'Landrat', who is the head of the administration of the 'Landkreis'. Furthermore, the Lower Water Agency, which is responsible for the 'practical' work and professional input, is organisationally subordinate to the Environmental Agency of the 'Landkreis', which itself is subordinate to the 'Department of Economics and Environment'. This organisational structure is somewhat precarious. Considering statements of the Lower Water Agency, it appears that executive decisions are more or less politically opportunistic rather than purely professional. Depending on the issue, the particular interests of non-water related sub-departments of the Lower Environment Authority, as well as those interests articulated from other sub-departments like 'Agriculture' or 'Structural Development' of the 'Department of Economics and Environment', not only influence the choice of key issues, but also the (final) decisions themselves. A kind of 'filter' effect that correlates with political priorities at the 'Landkreis' level can now, at the very least, be noticed. Furthermore, it was presumed that this constellation might have contributed to the fact that until recently the priority of the Water Authorities was on "more urgent" issues like improving the public wastewater disposal system and ensuring the public water supply. This would have required substantial financial, human and technical resources.

\subsubsection{Trans-boundary interrelations}

As previously mentioned, the present structure of water administration follows politicaladministrative borders. One might suspect that this impedes or even hinders the efficient and co-ordinated handling of a complex, transboundary biophysical system like the landscape water regime. On the other hand, one should not underestimate the implications of introducing or strengthening river basin management for existing institutional configurations and organisational structures (Göhler, 1997; for a general discussion on 'problems of fit' and 'problems of interplay', see Moss, 2001). In fact, the water regime of the 'Schraden' is strongly determined by the water inflow from the Brandenburg 'Landkreis OberspreewaldLausitz', and also from the 'Land Sachsen'. However, as found in the interviews from the 
Lower Water Agency, there are almost no joint activities, information exchanges or coordination meetings between the respective Water Authorities.

\subsubsection{Water Management Plans}

To actively and efficiently shape and regulate complex water management systems - ideally integrating all water user interests - water management framework plans (Wasserwirtschaftliche Rahmenpläne) and water management plans (Bewirtschaftungspläne) based on hydrological analysis are a necessary prerequisite. Taking this into account, $\S \S 36$ and $36 \mathrm{~b}$ of the federal Water Management Act (WHG) even determine that the Supreme Water Authority must provide such plans for all river basins. However, in Brandenburg there are few drafts for water management framework plans, even fewer drafts for detailed water management plans, and none are available for the 'Schraden'. Inevitably, in most cases the Water Authorities only 'react' rather incidentally to acute problems or demands of interest groups, other agencies or the public. This is certainly fostered by the fact that only the main canals or ditches are equipped - at least partly - with devices (Pegel) able to measure the water table. Thus, reliable monitoring and sanctioning is almost impossible.

It might be reasonable to presume that the above-described administration-related problems have negatively affected the performance of the Lower Water Agency responsible for the 'Schraden'. However, the question to what degree - if at all - each issue has contributed to the persistence of the water management problems in the region remains open. The next section will highlight some of the effects on ecology and land use caused or aided by the changes described in the sections above.

\subsection{Effects on ecology and land use}

Sustainability, quality and productivity of arable and grassland farming in the Brandenburg region heavily depend on a highly complex system of irrigation and drainage that was established before 1989. However, most of the water management devices such as weirs and dam plants have not been maintained since then. Instead, they have been operated without coordination (or not at all) and they have by now mostly deteriorated. The visible consequences are drought periods in the summer caused by high water run-off, and waterlogged plots in the spring, both of which frequently result in negative income effects for farmers. The decreasing availability of water throughout the year has already forced many farmers to reduce their portfolio of crops, which increasingly results in monocultures of non-water intensive crops. 
Nevertheless, intensive farming has continued in the 'Schraden', which further contributes to the deterioration of soils and the decrease of soil quality (AVP, 1998; own interviews).

In 1998, an agri-structural pre-planning (Agrarstrukturelle Vorplanung-AVP) was carried out. It focussed on water management problems in the 'Schraden' and stated that a 'businessas-usual' strategy would make agricultural land use impossible in the medium- or long-term. However, the same study also pointed out that sustainable farming land use, based on a functioning melioration system, was possible if changes towards a more habitat-adapted land use concept, as well as the renaturation of some open waters, were considered. Hence, sustainable agricultural production would not necessarily contradict the goals of nature conservation and water management (AVP, 1998). Still, interviews with most farmers in the region pointed out that given the unpredictability of market forces and agricultural policy, the costs and risks involved are considered to be high.

In many other transition countries, similar developments and effects can be observed. There, the transformation process has also resulted in the decay of irrigation and/or drainage systems. The restitution process has often caused or re-established highly-fragmented (private) land ownership, and has also resulted in smaller agricultural production units. Furthermore, essential parts of the previously co-operatively owned and managed melioration systems - i.e., non land-assets - were also redistributed to private owners/farmers. Due to external effects, legal insecurities and a lack of capital, the new owners have been very reluctant to invest in the maintenance of these systems. The facilities are now operated in an uncoordinated manner or not at all, and opportunistic and self-interested behaviour prevails. In socialist times, the technical infrastructures were built to suit the needs of huge production units with rather homogeneous interest structures. During the transition process, it has proved difficult to technically adapt the infrastructure to the needs of small units with heterogeneous interests, different production portfolios and economic potential (Theesfeld, 2001 and 2002; Penov, 2002; Busmanis, Zobena, Grinfelde and Dzalbe, 2002).

\section{Conclusions}

This paper illustrates that a plurality of reasons are responsible for the failure of the present institutional structure in the field of water management, and also of the plans to deal with the most serious problems in the 'Schraden' low moor region. These problems stem from intensive arable farming and complex melioration measures undertaken decades ago. The high water runoff caused by the increasing inability of the deteriorated soil to hold water cannot be prevented by existing weirs and dam plants, because these are mostly run-down and 
not operated in a co-ordinated manner. It has been argued that the reallocation of property rights over melioration systems, together with ineffective co-ordination mechanisms, have impeded appropriate land use. External effects, legal insecurities accompanied by enforcement problems, the fragmented land ownership structure and a high number of shortterm lease contracts have all combined to reduce the incentives for most farmers to take care of the melioration works individually. Due to its limited statutory rights in conjunction with its small financial room for manoeuvre, the present Water Association, as a local coordination mechanism, appears to be an inadequate substitute for the dissolved melioration co-operatives. Furthermore, the complete and time-intensive restructuring process on all levels of water administration has resulted in still-cumbersome, or even non-existing, interrelations between different administrative layers, and also in rare trans-boundary contacts. A lack of water management plans and the organisational embeddedness of the Lower Water Authority also impede effective administrative work. Adding to this are the profoundly heterogeneous interests of different user or interest groups, such as the conflict between farmers and environmentalists over the ground water table.

Due to low excludability and high rivalry, drainage and irrigation can be regarded as common pool resources, often associated with the 'social dilemma' of resource usage (Ostrom, 1998; Meinzen-Dick and Knox, 1999). Here, it is neither sufficient to simply establish a system of private property rights, nor to look for central government control. Numerous and extensive case studies suggest that essential property rights over resource water and over related infrastructure - e.g., rights to use and modify the infrastructure - should be transfered to collectively-organised local actors to overcome the 'social dilemma' (Ostrom, 1998; Vermillion, 1999). However, besides clearly-defined property rights over land and water (infrastructure) ${ }^{8}$, some necessary prerequisites for encouraging collective action would be organisational self-determination, as well as some governmental support with regard to technical advisory and extension services, and financial assistance for larger infrastructure investments (Vermillion, 1999). Furthermore, some basic stock in social capital and tradition in collective action are also making positive contributions (Moss, 2001).

The established concept of Water Associations as local co-ordination mechanisms - which rather successfully operates in the old 'Länder' - very much depends on effective property rights and clear accountabilities for the melioration works, as well as on some (financial) state support. In the presented case, however, not all of these preconditions are satisfactorily met. This is even more problematic since most facilities in the 'Schraden' have not been

\footnotetext{
8 "however disintegrated, property rights must be clarified if accountability is to be insured" (Stark, 1996: 1020).
} 
maintained for long periods of time, and relatively high investments are necessary to make them functional again. Considering the poor state of the 'Land' budget and the low potential of the Water Association to raise additional membership fees, the situation presents a significant challenge. 


\section{References}

AVP (1998). Agrarstrukturelle Vorplanung Wasserbewirtschaftungskonzept Schraden (Entwurf). Planungsbüro für Natur und Siedlung Lindenau/ PL3 Planungsbüro für ländliche Regionalentwicklung Berlin. Im Auftrag des Ministeriums für Ernährung, Landwirtschaft und Forsten vertreten durch das Amt für Flurneuordnung und ländliche Entwicklung Luckau.

BbgWG (1994). Brandenburgisches Wassergesetz vom 13.07.1994. GVB1.I/94, 302, ber. GVB1.I/97, 62. zuletzt geändert durch Gesetz vom 28.06.2000. GVB1.I/00, 90, 96, 129.

BbgWVG (1995). Gesetz über die Errichtung von Wasser- und Bodenverbänden in Brandenburg vom 13.03.1995. GVB1.I/95, 14.

Busmanis, Peteris, Aija Zobena, Inga Grinfelde and Inta Dzalbe (2001). Privatisation and Soil Drainage. In: Gatzweiler, F.; Hagedorn, K.; Judis, R. (eds.): Sustainable Agriculture in Central and Eastern European Countries: The Environmental Effects of Transition and Needs for Change. Proceedings of the ACE Phare Seminar, Aachen: Shaker Verlag (forthcoming).

Dokumentation zur Grundsatzentscheidung Komplexmelioration "Rechte Pulsnitzniederung" Teil II Z-Vorflut Grödener Binnengraben (1977). Plan- und Investträger: WWD Obere Elbe-Neiße, Ofm Cottbus. VEB Meliorationsbau Cottbus.

Dougherty, T. C. and A. W. Hall (1995). Environmental impact asseement of irrigation and drainage projects. FAO Irrigation and Drainage Paper 53. Rome.

Hagedorn, Konrad (2002). The Political Economy and Institutional Evolution of Privatisation and Restructuring of Agricultural Land in Central and Eastern Europe. Paper presented to the Regional Conference on Land Issues in Central and Eastern Europe and the CIS, Budapest, Hungary. April 3-6, 2002.

Hagedorn, Konrad and Franz Gatzweiler (2002). The evolution of institutions of sustainability in transition. In: Gatzweiler, F.; Hagedorn, K.; Judis, R. (eds.): Sustainable Agriculture in Central and Eastern European Countries: The Environmental Effects of Transition and Needs for Change. Proceedings of the ACE Phare Seminar, Aachen: Shaker Verlag (forthcoming).

Hagedorn, Konrad, Katja Arzt and Ursula Peters (2002). Institutional Arrangements for Environmental Co-operatives: a Conceptual Framework. In: Hagedorn, Konrad (Ed.): Co-operative Arrangements to Cope with Agri-environmental Problems. Cheltenham: Eward Elgar (2002).

Kalweit, Heino (1998). Schöpfung aus Wald und Wasser: Geschichte der Wasserwirtschaft in Brandenburg und Berlin. Stuttgart: Verlag Konrad Wittwer.

Könker, Hermann (1993). Neue Aufgaben für das Meliorationswesen in den neuen Bundesländern. Zeitschrift für Kulturtechnik und Landentwicklung 34, 147-156.

Landgraf, Lukas (2001). Chancen für den Landschaftswasserhaushalt in Brandenburg. In:Weigert, Bodo; Steineberg, Christian (eds.). Nachhaltige Entwicklung in der Wasserwirtschaft - Konzepte, Planung und Entscheidungsfindung. Interdisziplinäre Fachtagung am 27. und 28. Juni 2001 in Berlin. Schriftenreihe Wasserforschung 7. Berlin: Wasserforschung e.V. Interdisziplinärer Forschungsverbund Berlin. 
Laschewski, Lutz (1998). Von der LPG zur Agrargenossenschaft: Untersuchungen zur Transformation genossenschaftlich organisierter Agrarunternehmen in Ostdeutschland. Berlin: Ed. Sigma.

Lehrkamp, Horst (1987). Die Auswirkungen der Meliorationen auf die Bodenentwicklung im Randow-Welse-Bruch. Berlin: Humboldt-Universität zu Berlin. Dissertation

Meinzen-Dick, Ruth and Anna Knox (1999). Collective Action, Property Rights, and Devolution of Natural Resource Management: A Conceptual Framework. In: Ruth Meinzen-Dick, Anna Knox and Monica Di Gregorio (eds.): Collective Action, Property Rights and Devolution of Natural Resource Management - Exchange of Knowledge and Implications for Policy. Proceedings of the International Conference in Puerto Azul, The Philippines, 21-25 June, 1999, pp. 41-73.

MelAnlG (1994) Gesetz zur Klärung der Rechtsverhältnisse an Meliorationsanlagen vom 21.09.1994. BGB1. I S. 2550. unter Berücksichtigung der Änderung vom 20.12.1996. BGBl. I 2028.

Moss, Timothy (2001). Solving Problems of 'Fit' at the Expense of Problems of 'Interplay'? The Spatial Reorganisation of Water Management following the EU Water Framework Directive (draft), published by the Institute for Regional Development and Structural Planning, Erkner (website www.irs-net.de/workpaper3.htm).

Müller, Klaus, Verena Toussaint, Hans-Rudolf Bork, Konrad Hagedorn, Jürgen Kern, Uwe Jens Nagel, Jürgen Peters, Rolf Schmidt, Thomas Weith, Armin Werner, Axel Dosch and Annette Piorr (eds.) (2002). Nachhaltigkeit und Landschaftsnutzung - Neue Wege kooperativen Handelns. Weikersheim: Margraf-Verlag (forthcoming).

Müller, Klaus, Hans-Rudolf Bork, Axel Dosch, Konrad Hagedorn, Jürgen Kern, Jürgen Peters, Hans-Georg Petersen, Uwe Jens Nagel, Thomas Schatz, Rolf Schmidt, Verena Toussaint, Thomas Weith, Armin Werner and Albert Wotke (eds.) (2000). Nachhaltige Landnutzung im Konsens - Ansätze für eine dauerhaft-umweltgerechte Nutzung der Agrarlandschaften Nordostdeutschlands. Giessen: Focus-Verlag.

Ostrom, Elinor (1998). The Institutional Analysis and Development Approach. In: E. TusakLoehman and D. M. Kilgour (eds.): Designing Institutions for Environmental and Resource Management. Cheltenham UK and Northampton ME, USA: Eward Elgar, pp. 68-90.

Peinemann, Berthold (1995). Rechtsprobleme in der Praxis der Privatisierung ehemals volkseigenen landwirtschaftlich genutzten Grund und Bodens. Agrarrecht 25 (7), 225-232.

Penov, Ivan (2002). Irrigation and Water Usage in Bulgaria during Transition. In: Gatzweiler, F.; Hagedorn, K.; Judis, R. (eds.): Sustainable Agriculture in Central and Eastern European Countries: The Environmental Effects of Transition and Needs for Change. Proceedings of the ACE Phare Seminar, Aachen: Shaker Verlag (forthcoming).

Pollack, Peter (1991). Entwicklung und Stand des Meliorationswesens in den fünf neuen Bundesländern. Bonn: Köllen Druck + Verlag GmbH.

Schüler, R. (1991). Zur Entwicklung des landwirtschaftlichen Bodenrechts der ehemaligen DDR beim Übergang zur sozialen Marktwirtschaft. Agrarrecht 21 (2), 34-38.

Spaling, Harry and Barry Smit (1995). A conceptual model of cumulative environmental effects of agricultural land drainage. In: Agriculture, Ecosystems and Environment 53 (1995), pp. 99-108. 
Stark, David (1996). Recombiant Property in East European Capitalism. In: American Journal of Sociology, Vol. 101, No. 4 (January 1996), pp. 993-1027.

Swinnen, Johan F. M. and Erik Mathijs (1997): Agricultural Privatisation, Land Reform and Farm Restructuring in Central and Eastern Europe: a comparative analysis. In: J.F.M. Swinnen, A. Buckwell and E. Mathijs (eds.): Agricultural Privatisation, Land Reform and Farm Restructuring in Central and Eastern Europe. Aldershot, Brookfield USA, Singapore, Sidney: Ashgate, pp. 333-373.

Theesfeld, Insa (2001). Constraints for Collective Action in Bulgaria' Irrigation Sector. CEESA Discussion Paper No. 5/2001.

Theesfeld, Insa (2002). Constraints on Collective Action in Bulgaria's Irrigation Sector Empirical Results from the Village of Varbiza. In: Gatzweiler, F.; Hagedorn, K.; Judis, R. (eds.): Sustainable Agriculture in Central and Eastern European Countries: The Environmental Effects of Transition and Needs for Change. Proceedings of the ACE Phare Seminar, Aachen: Shaker Verlag (forthcoming).

Turnock, David (ed.)(1998). Privatization in Rural Eastern Europe. The Process of Restitution and Restructuring. Cheltenham, UK, Northhampton, MA, USA: Edward Elgar.

Verordnung über die Auflösung der Wasserwirtschaftsdirektion Oder Havel vom 28.01.1992. GVB1. II/92 S. 57.

Vermillion, Douglas L. (1999). Property Rights and Collective Action in the Devolution of Irrigation Systems Management. In: Ruth Meinzen-Dick, Anna Knox and Monica Di Gregorio (eds.): Collective Action, Property Rights and Devolution of Natural Resource Management - Exchange of Knowledge and Implications for Policy. Proceedings of the International Conference in Puerto Azul, The Philippines, 21-25 June, 1999, pp. 183-219.

WG (1982). Wassergesetz vom 02.07.1982. GB1. I Nr. 26, 467.

WHG (1996) Gesetz zur Ordnung des Wasserhaushalts vom 12.11.1996. BGBl. I 1695 unter Berücksichtigung der Änderung durch Art. 3 Abs. 1 Gesetz vom 27.12.2000 BGB1. I 2048.

Wiegand, S. (1994). Landwirtschaft in den neuen Bundesländern - Struktur, Probleme und zukünftige Entwicklung. Kiel: Vauk.

WVG (1991). Gesetz über Wasser- und Bodenverbände vom 12.02.1991. BGB1. I 405. 